\title{
The Influence of Pregnant Women Classes on Knowledge, Attitudes and Skills of Conducting Early Detection of Danger Signs during the Second Trimester of Pregnancy in Buleleng Regency
}

Desak Ketut Sugiartini
Magister of Public Health Program of
Institut Ilmu Kesehatan STRADA
Indonesia
Email:
publikasistrada@ gmail.com

Received: October 12, 2019

Accepted : February 13, 2020

Published : May 12, 2020

\begin{abstract}
Efforts need to be made to improve the implementation of pregnancy for pregnant women, one of which is to increase information and knowledge of mothers, attitudes and family support for the knowledge, attitudes and skills of Early Detection of Danger Signs during the Second Trimester of Pregnancy. This study aimed to determine the influence of pregnant women classes on knowledge, attitudes, and early detection of danger signs during trimester II pregnancy in the Buleleng Regency. The research method used observational research with a crosssectional approach. The population in this study were pregnant women who carried out pregnant women and visited at least 4 times as many as 124 mothers. Sampling was done by purposive sampling with a sample size of 82 pregnant women in TM II. The research instrument used a questionnaire with closed questions that had been validated and reliable was 0.6. The study was conducted at the Community Health Center in Singaraja City. Analysis of the data used in this study is the Logistic Regression statistical test with $\alpha 0.05$. The results of the study have a significant effect on the class of pregnant women on the knowledge of the $p$ value of 0.027 , there is no significant effect of the class of pregnant women on the attitude of the $p$ value of 0.347 and there is a significant influence on the class of pregnant women on the skills of pregnant women about the danger signs of TM II pregnancy $\mathrm{p}$ value of 0.008 . Conclusion there is the influence of the class of pregnant women on maternal knowledge and there is no effect of the class of pregnant women on the attitude of mothers to recognize the danger signs of pregnancy, there is the influence of classes of pregnant women on the skills of mothers to recognize the danger signs of pregnancy
\end{abstract}

Keywords: Pregnant mothers class, Attitude Knowledge and Skills

This is an open-acces article distributed under the terms of the Creative Commons Attribution-ShareAlike 4.0 International License. 


\section{INTRODUCTION}

Maternal Mortality Rate (MMR) is one important indicator in determining the degree of public health, especially the degree of women's health. The 2012 Indonesian Demographic and Health Survey (IDHS) said MMR in Indonesia was 359 per 100,000 live births, an increase compared to the 2007 IDHS results of 228 per 100,000 live births. Bali Province had a MMR of 114 per 100,000 live births in 2012. Bulleleng City had a MMR of 52.26 per 100,000 live births in 2015. This figure, despite a decline compared to the previous year, is still below the Bulleleng City strategic plan target of 50 per 100,000 live births (DKK Bulleleng, 2016).

The direct cause of maternal death in Buleleng is dominated by bleeding and preeclampsia/eclampsia (DKK Bulleleng, 2016). The cause of preeclampsia/ eclampsia cannot be prevented completely but its frequency can be reduced by providing counseling and supervision to pregnant women. Counseling for pregnant women that can be given one of them is about danger signs (Prawirohardjo, 2002). Recognizing danger signs early can prevent preeclampsia/ eclampsia (Wiknjosastro, 2008).

Knowing the danger signs is very important because if you are late to recognize the danger signs it will be too late to reach health facilities and be late to get services. Three late is the indirect cause of maternal death. Research at RSUD Dr. Soetomo in 2011-2013 stated that the delay which caused the most maternal deaths was $82.8 \%$ late in detecting danger signs (Widarta et al, 2015). This is in line with the case study in Purworejo which shows that one of the maternal death cases is caused by the inability to recognize the danger signs of pregnancy while at home (Hasnah et al, 2003). The Buleleng City Health Office mentioned that one of the indirect causes of maternal death in Buleleng was three late.

One effort to prevent the lack of knowledge of danger signs is to hold a Pregnant Women Class. Pregnant Mothers Class is a learning activity regarding pregnancy, childbirth, childbirth to baby care for pregnant women and their companions. Pregnant mother class is expected to make pregnant women have the ability to recognize danger signs during pregnancy, and childbirth so as to reduce maternal mortality and morbidity (DKK Buleleng, 2016).

Classes of pregnant women can increase interaction between participants so they will share experiences about pregnancy. This class can also increase interactions between pregnant women and midwives or health workers about pregnancy, including early recognition of danger signs of pregnancy, childbirth and childbirth. Participants are expected to experience an increase in their understanding and ability in early detection of danger signals (RI Ministry of Health, 2011). This study aimed to determine the effect of pregnant women classes on early detection behavior of danger signs during trimester II Pregnancy in the Buleleng Regency.

\section{METHODS}

The research method used is observational research with a cross-sectional approach. The population in this study was pregnant women who carried out pregnant women and visited at least 4 times as many as 124 mothers. Sampling was done by purposive sampling with a sample size of 82 pregnant women in TM II. Data collection techniques used in this study is primary data. Primary data is data obtained directly by researchers when research. Primary data in this study were obtained by asking respondents to fill out a questionnaire. All questions in the questionnaire were tested for validity and reliability first. Validity test uses the Pearson product moment test for linkert scale questions and biserial correlation tests for gutman scale questions. Reliability test uses Cronbach's alpha for all questionnaires. The value of the validity test of the knowledge, attitude and skills questionnaire was 0.83 and the reliability test value was 0.72 so that the research instrument could be used, the research was carried out at the Community Health Center in Singaraja City. Analysis of the data used in this study is the Logistic Regression statistical test with $\alpha 0.05$.

\section{RESULTS}

\section{Description of Research Sites}

This study used Community Health Center facilities located in the City of Buleleng region, namely areas with Community Health Center Buleleng 1. Community Health Center Buleleng 1 is a noninpatient Community Health Center located in Singaraja, Buleleng District. Community Health Center Buleleng 1 is led by a head of health center with a minimum education of S1 in the medical profession. 
Community Health Center Buleleng 1 has complete facilities with 3 main buildings. In the main front building is the registration of patients, emergency room, hall, laboratory, dental clinic and promkes. The second building consists of Poly KIA / KB, Warehouse, Office and vaccine storage room and the third building is a poly child and also a children's room. Where Community Health Center Buleleng 1 is a child-friendly. The total workforce in Community Health Center Buleleng 1 reached 48 people consisting of: doctors, nurses, midwives, and promkes health officers, administrative staff, dental nurses, laboratory assistants, pharmacy, CS and drivers. Community Health Center Buleleng 1 has conducted accreditation with intermediate results in 2017 and in 2020 July will carry out reaccreditation. Services performed at the Community Health Center Buleleng 1 include services inside and outside the building. Services outside the building include: Posyandu, Posbindu (PTM) Pusling and health counseling. Community Health Center Buleleng 1 has 120 patient visits per day. In 2019 the number of diseases that were most experienced by the people of Buleleng were Hypertension and DM.

\section{Description of Data Analysis}

Table 1 Distribution of frequency characteristics of the respondents about the danger signs of pregnancy Trimester II Community Health Center in Singaraja City 2019

\begin{tabular}{llcc}
\hline \multicolumn{1}{c}{ Variable } & \multicolumn{1}{c}{ Category } & Frequence & Percentage \\
\hline Age & Risk & 29 & 35,4 \\
& Not Risk & 53 & 64,6 \\
& Total & $\mathbf{8 2}$ & $\mathbf{1 0 0 , 0}$ \\
\hline Education Level & Not pass of Elementary & 2 & 2,5 \\
& Elementary School & 6 & 7,3 \\
& Junior High School & 22 & 26,8 \\
& Senior High School & 42 & 51,2 \\
& University & 10 & 12,2 \\
\cline { 2 - 4 } & Total & $\mathbf{8 2}$ & $\mathbf{1 0 0 , 0}$ \\
\hline Occupation & Not work & 59 & 71,9 \\
& Work & 23 & 28,1 \\
\cline { 2 - 4 } & Total & $\mathbf{8 2}$ & $\mathbf{1 0 0 , 0}$ \\
\hline \multirow{2}{*}{ Salary } & Under UMR & 46 & 56,1 \\
& Up to UMR & 36 & 43,9 \\
\cline { 2 - 4 } & Total & $\mathbf{8 2}$ & $\mathbf{1 0 0 , 0}$ \\
\hline Paritas & Primipara & 20 & 24,4 \\
& Multipara & 62 & 75,6 \\
\cline { 2 - 4 } & Total & $\mathbf{8 2}$ & $\mathbf{1 0 0 , 0}$ \\
\hline
\end{tabular}

Table 1 show that the majority of respondents (64.6\%) did not have an at-risk age ie aged 2035 years. The data also showed that the most recent respondents' education was SLTA $(51.2 \%)$ and SLTP (26.8\%). Most respondents (71.9\%) did not work or become housewives. The income of the respondent's family is more than below the Regional Minimum Wage at 56.1\%. Most respondents $(75.6 \%)$ had more than one child.

Table 2: Frequency distribution of respondents' knowledge, attitudes and skills recognizing the danger signs of TM II pregnancy at the Community Health Center Singaraja City in 2019.

\begin{tabular}{|c|c|c|c|}
\hline Variable & Category & Frequence & Percentage \\
\hline \multirow{4}{*}{ Education } & Less & 11 & 13,4 \\
\hline & Enough & 19 & 23,2 \\
\hline & Good & 52 & 63,4 \\
\hline & Total & 82 & 100,0 \\
\hline \multirow[t]{4}{*}{ Attitude } & Less & 1 & 1,2 \\
\hline & Enough & 29 & 35,4 \\
\hline & Good & 52 & 63,4 \\
\hline & Total & 82 & 100,0 \\
\hline
\end{tabular}




\begin{tabular}{llcc}
\hline Skills & Less & 32 & 39,0 \\
& Enough & 36 & 43,9 \\
& Good & 14 & 17,1 \\
\cline { 2 - 4 } & Total & $\mathbf{8 2}$ & $\mathbf{1 0 0 , 0}$ \\
\hline
\end{tabular}

Table 2 shows that the majority of respondents (63.4\%) had good knowledge and attitude about the danger signs of pregnancy, the respondents had the most skills in the sufficient category at $43.9 \%$, followed by the fewer categories at $39 \%$, and the good category at $17.1 \%$.

Table 3 Chi square test results (candidate selection) at the Community Health Center Singaraja City in 2019

\begin{tabular}{|l|c|c|c|c|}
\hline \multirow{2}{*}{$\begin{array}{c}\text { Independent } \\
\text { variable }\end{array}$} & \multirow{2}{*}{ AOR) } & \multicolumn{3}{c|}{ P Value } \\
\cline { 3 - 5 } & & Education & Attitude & Skill \\
\hline Age & 1,1 & 0,433 & 0,437 & 0,651 \\
\hline Education Level & 3,2 & $0,093^{*}$ & $0,113^{*}$ & 0,250 \\
\hline Occupation & 1,5 & 0,461 & 0,721 & 0,969 \\
\hline Salary & 1,8 & 0,488 & 0,553 & 0,816 \\
\hline Paritas & 3,0 & 0,388 & 0,698 & 0,369 \\
\hline $\begin{array}{l}\text { Pregnancy } \\
\text { mother class }\end{array}$ & 3,4 & $0,057^{*}$ & $0,165^{*}$ & $0,001^{*}$ \\
\hline
\end{tabular}

note: $*$ pass the selection

Table 3 shows some of the variables chosen to be analyzed for their effect on knowledge, attitudes and skills in recognizing danger signs of pregnancy. Variables analyzed for influence on knowledge are the level of education and classes of pregnant women, Variables analyzed for influence on attitudes are the level of education and classes of pregnant women, The variables analyzed for influence on skills are classes of pregnant women.

Table 4 Results of multinomial logistic regression tests on knowledge variables

\begin{tabular}{llll}
\hline Education* & Variable & P & RR \\
\hline Less & Intercept & $0,023^{* *}$ & \\
& Not join pregnancy mother class & $0,027^{* *}$ & 11,917 \\
& Join mother class & - & - \\
& Not pass of Elementary & 1,000 & 1,373 \\
& Elementary School & 0,410 & 3,580 \\
& Junior High School & 0,952 & 1,088 \\
& Senior High School & 0,709 & 0,623 \\
& University & - & - \\
\hline Enough & Intercept & 0,167 & \\
& Not join pregnancy mother class & 0,552 & 1,446 \\
& Join mother class & - & - \\
& Not pass of Elementary & 0,991 & $1,246 \mathrm{E} 7$ \\
& Elementary School & 0,988 & $1,151 \mathrm{E}-6$ \\
* & Junior High School & 0,930 & 0,920 \\
note : significant & Senior High School & 0,527 & 0,576 \\
& University & - & - \\
& & & \\
& & &
\end{tabular}


Table 5 shows that the variable that had a significant influence on knowledge was the class of pregnant women with a $\mathrm{p}$ value of 0.027 , indicating that the chance of not attending the class of pregnant women to have less knowledge was almost 12 times that of those attending the class of pregnant women.

Table 6 Results of multinomial logistic regression tests on attitude variables

\begin{tabular}{llll}
\hline Attitude & Variable & $\mathrm{p}$ Value & $\mathrm{RR}$ \\
\hline Less & Intercept & 0,347 & \\
& Not join pregnancy mother class & 0,957 & 1,219 \\
& Join mother class & - & - \\
& Not pass of Elementary & 0,993 & 1,104 \\
& Elementary School & 0,998 & 1,021 \\
& Junior High School & 0,986 & 0,898 \\
& Senior High School & 0,947 & 0,689 \\
& University & - & - \\
\hline Attitude & Variable & $\mathrm{p}$ Value & $\mathrm{RR}$ \\
\hline Enough & Intercept & 0,475 & \\
& Not join pregnancy mother class & 0,297 & 1,738 \\
& Join mother class & - & - \\
& Not pass of Elementary & 0,861 & 1,319 \\
& Elementary School & 0,963 & 1,060 \\
& Junior High School & 0,721 & 0,740 \\
& Senior High School & 0,183 & 0,353 \\
& University & - & - \\
& & & \\
\hline
\end{tabular}

note :* : reference category used is good attitude

Table 7 Results of multinomial logistic regression tests on the skills variable

\begin{tabular}{llll}
\hline Skill* & Variable & Attitude* & RR \\
\hline Less & Intercept & $0,008^{* *}$ & \\
& Not join pregnancy mother & $0,002^{* *}$ & 7,030 \\
& class & 0,386 & 2,930 \\
Enough & Intercept & 0,131 & \\
& Not join pregnancy mother & 0,098 & 2,761 \\
& Join pregnancy mother class & - & -
\end{tabular}

note :

* : reference category used is good skill

$* *$ : significant

\section{DISCUSSION}

1. Effect of Class of Pregnant Women on Knowledge of Knowing the Danger Signs of Pregnancy Trimester II at Community Health Center Buleleng Regency

The results of this study indicate the influence of the class of pregnant women on maternal knowledge about danger signs of pregnancy, childbirth, and childbirth. The class of pregnant women not only builds interaction between the facilitator and participants, but also interactions between participants so that a different exchange of experience is created (Ministry of Health Republic of 
Indonesia, 2011). This is consistent with what was stated by Notoatmodjo (2010) that experience is the beginning of behavior. Experience can be obtained alone or from others.

The material presented did not only come from the facilitator but also involved the participants. The involvement of these participants is shown by the participants being asked to read the $\mathrm{MCH}$ book and asked for their opinions on a particular material or case. Participants are also given the opportunity to answer other participants' questions or discuss with other participants. Notoatmodjo (2010) states participation discussion is one effective way to improve one's knowledge. The form of activities and interactions in the class of pregnant women allows the addition of information, especially about the danger signals to participants of the pregnant women class. Notoatmodjo (2007) stated that information is one that influences one's knowledge. The more information is received, the more knowledge is obtained. This is also in accordance with Lawrence Green's theory in Glanz et al (2008) which states that behavior change is influenced by three factors, namely predisposing factors, driving factors / reinforcement factors, and supporting / enabling factors. Predisposing factors are factors that provide a reason or motivation to behave. The reinforcement factor is the factor that follows the behavior that gives rewards for continuing, repeating and maintaining the behavior. Enabling / supporting factors are factors that enable or facilitate a person to act in the form of resources, facilities and infrastructure or facilities.

The class of pregnant women includes pushing / reinforcing factors and supporting / enabling factors in maternal behavior to recognize danger signs. The role of health workers in this case is the facilitator of the class of pregnant women and interaction with fellow participants is a motivating factor. Material obtained from MCH books, flipcharts, etc. is a means that becomes a supporting / enabling factor. Several studies have shown that classes of pregnant women influence the knowledge of mothers. Linarsih Research (2012) states there are differences in knowledge between before and after attending pregnant women classes. Mothers have increased knowledge after attending classes for pregnant women. Research conducted by Rahmawati (2015) also shows that classes of pregnant women influence the knowledge of mothers. Mothers who take classes in pregnant women are better informed than mothers who do not attend classes of pregnant women.

Research conducted by Yuniarsih et al (2017) also shows the same results. The results of this study indicate that there are significant differences in knowledge about healthy pregnancies between mothers who take classes with those who do not. Mothers who take classes in pregnant women have better knowledge than mothers who do not attend classes of pregnant women. The results of this study indicate other variables that influence knowledge besides the class of pregnant women, namely husband support. Husband's support includes social support that can influence behavior. This is consistent with what was stated by Notoatmodjo (2007) that behavior (in this case knowledge) can be influenced by one of them by social factors. Social factors or can be called social support is one of the driving factors / reinforcers that influence behavior change. The reinforcing factor is the factor that follows the behavior that gives rewards for continuing, repeating and maintaining the behavior (Glanz et al, 2008). Behavior intention theory developed by Snehandu (1980) also mentions social support as one that influences behavior (Notoatmodjo, 2010). Social support in this study that affects knowledge is support that comes from the husband.

Husband's support is important as the closest person to the mother and decision maker in the family. If there is a sign of danger, the husband must immediately bring the mother to health services. Husband SIAGA (ready, inter, guard) according to the BKKBN (2006) is alert to see the danger signs of pregnancy, planning a transportation system and blood donation if needed and accompanying the wife during labor. The husband also has the role of giving the wife proper information about health. The husband as the head of the household and the decision maker makes him a party that is more heard and followed by his wife's advice, especially regarding pregnancy care and prevention of complications (Winancy et al, 2016). Several studies have shown a relationship between husband support and maternal behavior. Research conducted by Sari et al (2017) shows the relationship between husband support and the accuracy of the ANC. Research conducted by Pramasanthi (2016) shows the relationship between husband support and adherence to implementing P4K. The results of this study also showed a number of variables that had the potential to influence maternal knowledge, although the results of the statistical tests did not indicate such influences such as education and support of health workers. This is consistent with what was 
stated by Notoatmodjo (2007) that behavior (in this case knowledge) can be influenced by education, mass media / information, social factors, and experience.

Education influences the learning process, the higher a person's education the easier it is to receive information. The more information received, the more knowledge is gained (Notoatmodjo, 2007). Astuti's research (2012) shows a relationship between education and knowledge of danger signs of pregnancy. Support of health workers is important as a source of information and motivation for mothers. Health workers as competent parties in providing information and advice regarding pregnancy, childbirth, and childbirth, including danger signs. This form of support can be in the form of regular antenatal care (ANC) services. All respondents in this study received regular ANC services. Research conducted by Khuzaiyah et al (2015) proves there are differences in knowledge of the danger signs of pregnancy between pregnant women who do ANC regularly and those who do not. Pregnant women who carry out regular pregnancy checks are more knowledgeable than those who do not.

\section{Effect of Pregnant Women's Classroom on Attitudes to Know the Dangers of Pregnancy Signs.}

This research shows that there is no influence of class of pregnant women on the attitude to recognize danger signs. The mother may know the danger signs but may not necessarily assume that it can actually be dangerous for her and her baby. The opposite can happen, mothers respond well to danger signs without knowing that it is indeed dangerous for the mother and her baby. This is what probably caused the class of pregnant women not to influence attitudes in this study. This is consistent with what was stated by Notoatmodjo (2010) that not all behaviors follow certain patterns. Good behavior is not necessarily preceded by good knowledge and attitude. Research conducted by Setiyadi (2015) shows that there is no significant relationship between attitude and HIV / AIDS prevention behavior. These results are in line with research conducted by Kartikawati et al (2014) about the effect of the toddler class on improving mothers' knowledge, attitudes and skills. The study compared behaviors before and after attending toddler mother classes and compared them with groups of mothers who did not attend toddler mother classes. The results show that both groups experienced an increase in attitude but this increase was even higher in the group who did not attend the toddler mother class.

This is different from the results of research Ariyani et al (2012). This study shows the effect of antenatal classes on the behavior (knowledge, attitudes, and actions) of pregnant women regarding pregnancy, childbirth, childbirth, newborns, contraception, and delivery preparation. The results of this study indicate that the implementation of antenatal classes provides behavioral changes including better attitude than ANC activities carried out per individual. Khafidzoh's research (2016) also shows the relationship between classes of pregnant women with maternal knowledge and attitudes. Another possibility that caused the results of the study did not show the influence of the class of pregnant women on maternal attitudes was that all respondents who either attended the pregnant mothers class or not from the beginning had a good attitude. This can be seen from the results of the descriptive analysis that most respondents of both groups have a good attitude and only a few are behaving less.

This is due to the limitations of the study, this study only examined the attitudes of mothers after attending classes of pregnant women but did not examine the attitudes of mothers before attending classes of pregnant women. Lack of sample can also be the cause, because in the table it can be seen that mothers who take classes in pregnant women behave more favorably than mothers who do not attend classes of pregnant women.

\section{Effect of Pregnant Women Classes on Skills to Recognize Dangerous Signs of Pregnancy.}

This study shows the influence of the class of pregnant women on maternal skills to recognize danger signs of pregnancy, childbirth, and childbirth. The learning process in the classroom of pregnant women is carried out in a variety of methods and media that are tailored to the needs of the mother. Learning methods in the class of pregnant women are not only lectures but also by demonstration, giving pictures and videos, discussions, simulations, and so on (Ministry of Health Republic of Indonesia, 2011). These various methods allow mothers to understand danger signs more fully. Mothers not only hear the theory, but also can see pictures of examples of danger 
signs of pregnancy, childbirth, and childbirth. The facilitator can also demonstrate the introduction of danger signals such as how to properly check for swelling. This causes not only increased knowledge but also increased mother's skills.

The class of pregnant women not only builds interaction between the facilitator and participants, but also interactions between participants so that a different exchange of experience is created (Ministry of Health Republic of Indonesia, 2011). Other participants' experiences can also hone their skills. Participants who have experienced danger signs in a previous pregnancy can share their experiences. This is consistent with what was stated by Notoatmdjo, 2010) that experience can initiate behavior. Experience can be experienced alone and can be sourced from the experiences of others.

\section{Effect of Pregnant Women Classes on Knowledge, Attitudes and Skills to Know the Signs of Pregnancy Danger}

There is the influence of the class of pregnant women on knowledge, there is no effect of the class of pregnant women on the attitude to recognize danger signs and the effect of maternal class skills on pregnancy danger signs. This is also in accordance with Lawrence Green's theory in Glanz et al (2008) which states that behavior change is influenced by three factors, namely predisposing factors, driving factors / reinforcement factors, and supporting / enabling factors. Predisposing factors are factors that provide a reason or motivation to behave. The reinforcement factor is the factor that follows the behavior that gives rewards for continuing, repeating and maintaining the behavior. Enabling / supporting factors are factors that enable or facilitate a person to act in the form of resources, facilities and infrastructure or facilities.

The class of pregnant women includes pushing / reinforcing factors and supporting / enabling factors in maternal behavior to recognize danger signs. The role of health workers in this case is the facilitator of the class of pregnant women and interaction with fellow participants is a motivating factor. Material obtained from MCH books, flipcharts, etc. is a means that becomes a supporting / enabling factor. Several studies have shown that classes of pregnant women influence the skills of mothers. Linarsih research (2012) states there are differences in skills between before and after attending pregnant women classes. Mothers have improved skills after attending a class of pregnant women. The research results of Ariyani et al (2012) show the same thing. This study shows the effect of antenatal classes on maternal actions in preparing for labor. Mothers who took antenatal classes experienced an increase in actions than mothers who did not attend antenatal classes.

The influence of the class of pregnant women on these skills is reinforced by good knowledge which is also influenced by the class of pregnant women. This is in accordance with WHO (World Health Organization) behavior theory in Notoatmodjo (2010) which states that knowledge is one form of thought and feeling (thoughs and feelings) which is one of the reasons for one's actions. Good knowledge tends to display good actions. Mothers who already have knowledge about pregnancy who are likely to be at risk will be more alert to pregnancy problems. This vigilance will encourage the speed of decision making in seeking help when faced with problems, especially danger signs (Hasnah et al, 2003). Research conducted at the Medan Deli Health Center in 2015 proved that knowledge of pregnancy danger signs relates to the act of detecting pregnancy danger signs (Ardillah et al, 2015).

The results of this study indicate the influence of the class of pregnant women on knowledge and skills but does not affect the attitude, although the table shows a better attitude in mothers who take classes in pregnant women. This is likely due to the small number of samples and the different pressure points of questionnaire questions. The attitude questionnaire emphasizes the anxiety, worries, and vigilance of the mother when experiencing a danger sign and the mother's view of the danger sign, while the skills questionnaire focuses on the mother's ability to recognize the danger sign without asking the mother's actions if she has experienced a previous danger sign (whether immediately check with the health service or no). This is different from the research conducted by Ariyani et al (2012). The study shows the influence of antenatal classes on maternal behavior both knowledge, attitudes, and actions. Mothers who took antenatal classes behaved better than mothers who did not attend antenatal classes.

Skills or actions are also influenced by various factors. Lawrence Green's theory states that the three factors that influence behavior change are predisposing, reinforcing, and enabling factors (Glanz et al., 2008). In this research, although several factors do not affect skills, but there are factors 
that have the potential to influence skills, namely the use of the $\mathrm{MCH}$ handbook. Utilization of the $\mathrm{MCH}$ handbook is a possible factor. The MCH Handbook contains information about pregnancy, childbirth, and childbirth. Mothers and families who have a $\mathrm{MCH}$ book are expected to understand about pregnancy, childbirth, and childbirth, including danger signs. Information on the danger sign is accompanied by supporting images (Ministry of Health Republic of Indonesia, 2015). Pregnant women classes also use the MCH book as a reference material. Research conducted by Ainiyah (2017) shows the relationship between the use of MCH books with the level of knowledge and health behavior of pregnant women.

\section{CONCLUSION}

1. There is an effect of the class of pregnant women on the knowledge of mothers to recognize the danger signs of pregnancy, childbirth, and childbirth. Mothers who do not attend the class of pregnant women have almost 12 times the opportunity to have less knowledge than mothers who take classes of pregnant women.

2. There is no influence of the class of pregnant women on the attitude of mothers to recognize danger signs of pregnancy, childbirth, and childbirth. The results of the descriptive analysis showed that mothers who took the class of pregnant women had more good attitudes than mothers who did not attend classes of pregnant women but the results of statistical tests did not show any influence.

3. There is the influence of the class of pregnant women on the skills of mothers to recognize danger signs of pregnancy, childbirth, and childbirth. Mothers who did not attend the class of pregnant women had 7 times the opportunity to have less skill than mothers who took the class of pregnant women.

4. There is the influence of the class of pregnant women on knowledge; there is no influence of the class of pregnant women on the attitude to recognize danger signs and the effect of maternal class skills on danger signs of pregnancy.

\section{REFERENCES}

Ainiyah, NH. 2017. Hubunganan pemanfaatan buku kesehatan ibu dan anak (KIA) dengan tingkat pengetahuan dan perilaku kesehatan ibu hamil trimester iii di puskesmas Jagir Surabaya. Tesis. Program Pasca Sarjana Universitas Aisyiyah Yogyakarta.

Ardillah, S, Sanusi, SR \& Fitria, M. 2015. „Hubungan pengetahuan dan sikap terhadap tindakan ibu hamil tentang deteksi dini tanda-tanda bahaya kehamilan di puskesmas MedanDeli tahun 2015. Jurnal Gizi Kesehatan Reproduksi dan Epidemiologi, vol. 2, no. 2.

Arikunto, S. 2011. Prosedur penelitian-suatu pendekatan praktik. Jakarta: Rhineka Cipta.

Ariyani, NW, Suindri, NN \& Budiani, NN. 2012. „Pengaruh pelaksanaan kelas antenatal terhadap perilaku ibu hamil. Jurnal Skala Husada, vol. 9, no.1, April 2012.

Astuti, HP. 2012. „Hubungan karakteristik ibu hamil dengan tingkat pengetahuan tentang tanda bahaya pada kehamilan di puskesmas Sidoharjo kabupaten Sragen. Jurnal KESMADASKA, vol. 3, no. 2, Juli 2012.

Azwar, S. 2011. Sikap manusia teori dan. pengukurannya. 2 nd ed. Yogyakarta: Pustaka Pelajar.

BKKBN. 2006. „Peranan suami dalam membangun bahtera keluarga sakinah berkualitas. bengkulu.bkkbn.go.id/data/Documents/booklet\%20gambar.pdf. diakses tanggal 14 Desember 2017.

Departemen Kesehatan Republik Indonesia. 2001.Buku pedoman pengendalian tanda bahaya pada kehamilan, persalinan dan nifas. Jakarta : Depkes RI.

. 2009. Pegangan fasilitator kelas ibu hamil. Jakarta : Depkes RI

Destria, D. 2010. „Faktor-faktor yang berhubungan dengan tingkat pemahaman ibu hamil terhadap pesan antenatal care yang terdapat di dalam buku kia. Skripsi. FK UNDIP.

Dinas Kesehatan Bulleleng . 2012. Proposalpemberdayaan kelas hamil dan optimalisasi puskesmas poned (pelayanan obstetri dan neonatal emergency dasar) dalam upaya penurunan angka kematian ibu di kota Bulleleng. Bulleleng : DKK Bulleleng . . 2016. Profil kesehatan kota Bulleleng tahun 2015. Bulleleng : DKK Bulleleng .

Fertman, CI \&Allenswort, DD. 2010. Health promotion programs from theory to practice.San Fransisco :Jossey Bass 
Fuada, N \& Setyawati, B. 2015. „Pelaksanaan kelas ibu hamil di Indonesia. Jurnal Kesehatan Reproduksi, vol. 6, no. 2, Agustus 2015.

Glanz, K, Rimer, BK\&Viswanath K. 2008. Health behavior and health education: theory, research, and practice. San Francisco: Jossey Bass.

Green, LW \& Kreuter, MW. 2005. Health program planning: an educational and ecological approach. New York: McGraw-Hill.

Harnindita, ID. 2015. „Hubungan usia, pendidikan dan paritas dengan sikap ibu hamil dalam mengenal tanda-tanda bahaya kehamilan di puskesmas Piyungan Bantul tahun 2015. Skripsi. STIKES Aisyiyah Yogyakarta.

Haryanti, RS. 2008. Perbedaan tingkat pengetahuan antara primigravida dan multigravida tentang tanda bahaya kehamilan di puskesmas Sibela Bulleleng. KTI. FK UNS.

Hasnah \& Triratnawati, A. 2003. „Penelusuran kasus-kasus kegawatdaruratan obstetri yang berakibat kematian maternal studi kasus di RSUD Purworejo, Bali. Makara Kesehatan, vol. 7, no. 2, Desember 2003.

Hendarwan, H. 2005. „Faktor-faktor yang berhubungan dengan perilaku ibu balita dalam pencarian pengobatan pada kasus-kasus balita dengan gejala pneumonia di kabupaten Serang. Media Litbang Kesehatan, vol. XV, no. 3, tahun 2005.

Isdiaty, FN \& Ungsianik, T. 2013. „Pengetahuan tanda bahaya kehamilan dan perilaku perawatan kehamilan pada ibu hamil trimester III. Jurnal Keperawatan Indonesia, vol 16, no.1, Maret 2013.

Kartikawati, SL, Sutedja, E \& Dzulfikar DLH. 2014. „Pengaruh kelas ibu balita terhadap peningkatan pengetahuan, sikap, dan keterampilan ibu balita dalam merawat balita di wilayah kerja puskesmas Sukarasa kota Bandung. Bhakti Kencana Medika, vol. 4, no. 1, Maret 2014.

Khafidzoh, A. 2016. „Hubungan Keikutsertaan Kelas Ibu Hamil dengan Perilaku Ibu dalam Perawatan Masa Nifas (Studi di Wilayah Kerja Puskesmas Cepiring Kabupaten Kendal). Skripsi. FKM Undip.

Kementerian Kesehatan Republik Indonesia. 2011. Pedoman pelaksanaan kelas ibu hamil. Jakarta : Kemenkes RI.

2013. Buku saku pelayanan kesehatan ibu di fasilitas kesehatan dasar dan rujukan : pedoman bagi tenaga kesehatan. Jakarta : Kemenkes RI.

2015. Petunjuk teknis penggunaan buku kesehatan ibu dan nak. Jakarta : Kemenkes RI. 2016. Buku kesehatan ibu dan anak. Jakarta : Kemenkes RI dan JICA.

Lestari, PB, Susetyo \& Santoso, HYD. 2012. „Hubungan antara pemanfaatan buku KIA dengantingkat pengetahuan dan sikap ibu hamiltentang tanda- tanda bahaya kehamilandi BPMNy. EKecamatan Ambarawaperiode Januari-Maret 2012. Jurnal Kebidanan Panti Wilasa, vol. 3 ,no. 1, Oktober 2012.

Linarsih. 2012. „Pengaruh kelas ibu hamil terhadap peningkatan pengetahuan dan keterampilan ibu hamil mengenai kesehatan ibu dan anak di wilayah puskesmas Sempor II kabupaten Kebumen. Skripsi. FKM UI.

Mahardani. 2011. „Faktor-faktor yang berhubungan dengan pengetahuan ibu hamil dalam deteksi dini tanda bahaya kehamilan di wilayah kerja puskesmas Sawan I, Kabupaten Buleleng Bali. Skripsi. FKM UI.

Mahmudah. 2013.,,Tingkat pengetahuan ibu hamil tentang tanda bahaya kehamilan di BPM. Tri Tedjo, Bendosari, Sukoharjo. Jurnal Maternal, vol. 8, no.8.

Manuaba, IGB. 2007. Pengantar kuliah obstetri. Jakarta : EGC.

Mayasari, AS. 2010. „Perbedaan tingkat pengetahuan antara primigravida dan multigravida tentang tanda bahaya kehamilan di puskesmas Sibela Bulleleng .Skripsi. FK UNS.

Murti, B. 2003.Prinsip dan metode riset epidemiologi. Yogyakarta: UGM. Notoatmodjo, S. 2007. Pendidikan dan perilaku kesehatan. Jakarta :Rineka Cipta 2010. Promosi kesehatan (teori dan aplikasi).Jakarta : Rineka Cipta. 2012a. Metodologi penelitian kesehatan. Jakarta : Rineka Cipta.

2012b. Promosi kesehatan dan perilaku kesehatan. Jakarta: Rineka Cipta. 
Porter, CM. 2016. "Revisiting precede-proceed: a leading model for ecological and ethical health promotion. Health Education Journal, vol. 75, no. 6.

Pramasanthi, RI. 2016. „Hubungan pengetahuan ibu hamil dan dukungan suami dengan kepatuhan melaksanakan program perencanaan persalinan dan pencegahan komplikasi (P4K) di Kota Salatiga. Jurnal Sistem Kesehatan, vol. 1, no. 4.

Prawirohardjo, S. 2002. Buku pedoman praktis pelayanan kesehatan maternal dan neonatal. Jakarta : YBPSP

Rahmawati, EBS. 2015. „Pengaruh keikutsertaan ibu di kelas ibu hamil terhadap praktik inisiasi menyusu dini (IMD) pada bayi usia 6-8 bulan di wilayah kerja puskesmas Sisir kota Batu. Tesis. FKM UNAIR.

Rahmawati, P, Martini, S \& Wahyuni, CU. 2014. „Analisis determinan kematian maternal pada masa nifas di kabupaten Sidoarjo tahun 2012. Jurnal Berkala Epidemiologi, vol. 2, no. 1, Januari 2014.

Rashad, WA \& Esa, RM. 2010. „Women“s awareness of danger signs of obstetrics complications. Journal of American Science, vol. 6, no. 10, tahun 2010.

Sarafino, EP. 1994.Health psychology: biopsychological interaction. Kanada:John Wiley \& Sons, Inc.

Sarason, IG, Levine, HM, Basham, RB, \& Sarason, BR. 1983. „Assesingsocial support: the social support questionnaire.Journal of Personalityand Social Psychology, vol. 44, no. 1.

Sari, RN \& Kusparlina, EP. 2017. „Hubungan dukungan suami dengan ketepatan antenatal care di desa bagi kabupaten Madiun. Seminar Nasional dan Presentasi Hasil-Hasil Penelitian serta Pengabdian Masyarakat bidang Kesehatan. Edisi September 2017.

Setiyadi, NA. 2015. „Hubungan antara pengetahuan dan sikap dengan perilaku pencegahan HIV/AIDS pada remaja komunitas anak jalanan di kabupaten Kudus. Prosiding Seminar Nasional Fakultas Ilmu Kesehatan.

Setyowati, A. 2010. „Hubungan karakteristik ibu hamil primigravida dengan tingkat pengetahuan tentang tanda bahaya kehamilan di RB YKWP (studi kasus di desa Kangkung Senggrong, kecamatan Mranggen, kabupaten Demak tahun 2010). Skripsi. Universitas Muhammadiyah Semarang.

Sudarma, M. 2008. Sosiologi untuk kesehatan. Jakarta: Salemba Medika.

Sukesih, S. 2012. „Faktor-faktor yang berhubungan dengan pengetahuan ibuhamil mengenai tanda bahaya dalam kehamilan di Puskesmas Tegal Selatan. Skripsi. FKM UI.

Sulaeman, ES, Murti, B \& Waryana. 2015. „Aplikasi model precede-proceed pada perencanaan program pemberdayaan masyarakat bidang kesehatan berbasis penilaian kebutuhan kesehatan masyarakat. Jurnal Kedokteran Yarsi, vol. 23, no. 3.

Waryana, 2016. Promosi kesehatan, penyuluhan, dan pemberdayaan masyarakat. Yogyakarta : Nuha Medika.

Widarta, DG, Laksana, MAC, Sulistyono, A \& Purnomo, W. 2015. „Deteksi dini risiko ibu hamil dengan kartu skor poedji rochjati dan pencegahan faktor empat terlambat. Majalah Obstetri \& Ginekologi, vol. 23, no. 1 Januari - April 2015.

Winancy, Raksanegara, AS, \& Fuadah Y. 2016. „Sikap suami tentang tanda bahaya kehamilan, persalinan, dan nifas (perbandingan metode brainstorming dan buzz group). Jurnal Ilmu dan Teknologi Kesehatan, vol. 4, no. 1.

Winkjosastro, H. 2008. Ilmu kebidanan. Jakarta: EGC.

Yuniarsih, SM, Indriono, A, \& Widhowati, SS. 2017. „Perbedaan tingkat pengetahuan tentang kehamilan sehat dengan indikator kesehatan ibu hamil yang mengikuti kelas ibu hamil. Media Ilmu Kesehatan, vol. 6, no. 1, April 2017. 